\title{
Brain Natriuretic Peptide and NT-proBNP Levels Reflect Pulmonary Artery Systolic Pressure in Trekkers at High Altitude
}

\author{
D. R. WOODS ${ }^{1,2,3,4}$, A. MELLOR ${ }^{1,2,5}$, J. BEGLEY ${ }^{6}$, M. STACEY ${ }^{1}$, J. O'HARA ${ }^{7}$, \\ A. HAWKINS ${ }^{6}$, J. YARKER ${ }^{1}$, S. FOXEN ${ }^{1}$, C. SMITH ${ }^{1}$, C. BOOS ${ }^{1,8}$ \\ ${ }^{1}$ Defence Medical Services, ${ }^{2}$ MDHU, Northallerton, ${ }^{3}$ University of Newcastle, Newcastle \\ upon Tyne, ${ }^{4}$ Northumbria and Newcastle NHS Trusts, ${ }^{5}$ James Cook University Hospital, \\ Middlesborough, ${ }^{6}$ Department of Biochemistry, Poole Hospital, Poole, ${ }^{7}$ Research Institute \\ for Sport, Physical Activity and Leisure, Leeds Metropolitan University, Leeds, ${ }^{8}$ Department \\ of Cardiology, Poole Hospital NHS Foundation Trust, Poole, United Kingdom
}

Received March 22, 2013

Accepted June 13, 2013

On-line July 17, 2013

\begin{abstract}
Summary
Our objective was to evaluate the utility of the natriuretic peptides BNP (brain natriuretic peptide) and NT-proBNP as markers of pulmonary artery systolic pressure (PASP) in trekkers ascending to high altitude (HA). 20 participants had BNP and NTproBNP assayed and simultaneous echocardiographic assessment of PASP performed during a trek to $5150 \mathrm{~m}$. PASP increased significantly $(p=0.006)$ with ascent from $24 \pm 4$ to $39 \pm 11 \mathrm{~mm} \mathrm{Hg}$ at $5150 \mathrm{~m}$. At $5150 \mathrm{~m}$ those with a PASP $\geq 40 \mathrm{~mm} \mathrm{Hg}(\mathrm{n}=8)$ (versus those with $\mathrm{PASP}<40 \mathrm{~mm} \mathrm{Hg}$ ) had higher post-exercise BNP (pg/ml): $54.5 \pm 36$ vs. $13.4 \pm 17(p=0.012)$. Their resting BNP at $5150 \mathrm{~m}$ was also higher: $57.3 \pm 43.4$ vs. $12.6 \pm 13(p=0.017)$. In those with a pathological ( $\geq 400 \mathrm{pg} / \mathrm{ml}$ ) rise in NT-proBNP at $5150 \mathrm{~m}(\mathrm{n}=4)$ PASP was significantly higher: $45.9 \pm 7.5$ vs. $32.2 \pm 6.2 \mathrm{~mm} \mathrm{Hg}(p=0.015)$. BNP and NT-proBNP may reflect elevated PASP, a central feature of high altitude pulmonary oedema, at $\mathrm{HA}$.
\end{abstract}

\section{Key words}

Hypoxia • Altitude • BNP • NT-proBNP • Pulmonary artery systolic pressure

\section{Corresponding author}

David Woods, Royal Victoria Infirmary, Newcastle upon Tyne, NE19 2AH, UK. E-mail: DoctorDRWoods@aol.com

\section{Introduction}

Large numbers of people trek to high altitude
(HA) each year, of which a significant number develop pulmonary hypertension and succumb to HA illnesses such as high altitude pulmonary oedema (HAPE). Currently there is no useful bed-side blood test that can aid in the diagnosis of pulmonary hypertension or HAPE.

The cardiac natriuretic peptides, BNP (active) and NT-proBNP (inactive), are derived from a prohormone, proBNP, stored in cardiomyocytes (Hall 2005). Their release is stimulated primarily by myocardial wall tension related to cardiomyocyte stretch and as such they are classically associated with congestive cardiac failure (CCF) secondary to left ventricular dysfunction (LVD) (Hall 2005). However, it is increasingly recognized that hypoxia may also stimulate their release (Casals et al. 2009, Due-Andersen et al. 2008) and we have recently reported a rise in BNP (Woods et al. 2011a) and NT-proBNP (Woods et al. 2012) at high altitude (HA). Further, they may also be elevated in conditions associated with pulmonary artery hypertension at sea-level (SL) (Blyth et al. 2007) and have been correlated with pulmonary artery systolic pressure (PASP) pre- and post-exercise (Kerr et al. 2008).

The hypoxia of HA leads to pulmonary vasoconstriction, which in turn contributes to an increase in PASP, which may be associated with elevated natriuretic peptides at SL. An exaggerated pulmonary vascular response is of central importance in the development of high altitude pulmonary oedema (HAPE) (Bartsch et al. 2005, Maggiorini et al. 2001) but symptoms of HAPE can 
be difficult to distinguish in the early stages. Progressive shortness of breath with a dry cough may occur but is difficult to distinguish from that which commonly occurs at HA (Hall et al. 2011). Inspiratory lung crackles are a later feature of HAPE but again are not pathognomic (Hall et al. 2011). Only as the disease progresses with orthopnoea through to the typical pink frothy sputum of frank pulmonary oedema does the diagnosis become obvious. Early detection of HAPE is therefore challenging and any simple test with the potential to facilitate early diagnosis and treatment could be life-saving.

Conventionally, assessment of PASP either requires invasive assessment, not practical in the field, or non-invasive assessment using trans-thoracic echocardiography that requires a skilled operator and expensive equipment not usually available on conventional expeditions to HA. BNP and NT-proBNP can be assayed on a small venous blood sample and BNP results can be readily available in the field with little expertise using a point-of-care (POC) testing device.

Although we have previously reported an association between BNP and NT-proBNP and acute mountain sickness (AMS) (Woods et al. 2011a, Woods et al. 2012) the evidence above prompted us to establish if NT-proBNP/BNP could also be driven by, and act as a marker for, an elevated PASP in previously healthy individuals exposed to HA.

\section{Methods}

The study was approved by the Ministry of Defence Research Ethics Committee (MODREC), UK and conformed to the standards set in the Declaration of Helsinki. All participants gave written informed consent.

As previously described (Woods et al. 2012) twenty healthy participants from the UK military participating in Exercise Khumbu Ramble, a trek in Nepal were studied. Five of the subjects had been trekking at high altitude previously, not in the preceding 6 months, and none were HAPE-susceptible. The group flew from Kathmandu (Kat) to Lukla (2840 m) by light aircraft and commenced trekking on day 1 . Three main altitudes were used to study participants: $3440 \mathrm{~m}$ (day 2); $4270 \mathrm{~m}$ (day 6) and $5150 \mathrm{~m}$ after ascent of Kala Patthar $(5643 \mathrm{~m})$ on day 10. Participants were studied immediately on arrival after a day of trekking ("postexercise") and the following morning at rest.

Echocardiography and venous blood samples (from antecubital fossa) were performed post-exercise and at rest at the main study altitudes. Oxygen saturation (digitally on warm hands at rest) was measured using a Nellcor NP-20 pulse oximeter (Covidian, MA, USA). BNP was assayed using a point-of-care analyzer (Biosite Triage Meter with BNP tests strips, Alere Ltd, Cheshire, UK) in the field and NT-proBNP was assayed on frozen samples on return to the UK using the Roche NT-proBNP assay (Roche Diagnostics, Mannheim, Germany). As NTproBNP is renally cleared renal function was assessed by serum creatinine. PASP was estimated from the maximum velocity of the trans-tricuspid gradient using continuous wave Doppler imaging added to a fixed value of $5 \mathrm{~mm} \mathrm{Hg}$ as previously validated (Yock and Popp 1984). Further off line processing was carried out by a consultant cardiologist (CB), who was blinded to any of the other data, to ascertain PASP.

For statistical calculations the software package SPSS 14.0 was used. Parametric or non-parametric statistical tests were applied after performing the ShapiroWilks statistic.

Changes in dependent variables between altitudes were initially tested by Student's paired t test or Wilcoxon signed ranks test. For independent variables an independent-samples $\mathrm{t}$ test or Mann Whitney test was used. Either a within participants ANOVA or a Friedman test was performed to investigate any serial changes in measures (e.g. PASP or BNP) with ascent. BNP and NTproBNP levels were also interrogated according to a $\mathrm{PASP} \geq 40 \mathrm{~mm} \mathrm{Hg}$ or $<40 \mathrm{~mm}$ since the maximal PASP response in healthy participants to hypoxia is considered $40 \mathrm{~mm} \mathrm{Hg}$ (Grunig et al. 2000). Spearman's rank correlation between BNP, NT-proBNP and PASP was performed, as was a ROC (receiver operating characteristic) analysis to investigate the utility of the natriuretic peptides in identifying a PASP $>40 \mathrm{~mm} \mathrm{Hg}$.

A $p$ value $<0.05$ was considered significant throughout. All data are reported as mean \pm SD ( \pm range where appropriate) except for Figure 2 (mean \pm SEM).

Participants were excluded from analysis once they took drugs to aid acclimatization.

\section{Results}

Patient demographics have been previously reported (Woods et al. 2012), in brief the 20 subjects ( 9 female, 11 male) were $36.1 \pm 1.9$ years old (range 22-51 yrs); $174.5 \pm 1.7 \mathrm{~cm}$ high and weighed $76.8 \pm 3.1 \mathrm{~kg}$ (all data mean \pm SEM). One subject had taken drugs known to affect acclimatization by $4270 \mathrm{~m}$, and 5 participants by $5150 \mathrm{~m}$. 
Table 1. Oxygen saturation, PASP, BNP and NT-proBNP with ascent to $5150 \mathrm{~m}$ in the Khumbu valley, Nepal ( $n=20$ at 1300 and $3400 \mathrm{~m}, \mathrm{n}=19$ at $4270 \mathrm{~m}$ and $\mathrm{n}=15$ at $5150 \mathrm{~m}$ ). The BNP and NT-proBNP data have previously been reported (Woods et al. 2012) but not in the context of PASP.

\begin{tabular}{|c|c|c|c|c|}
\hline Altitude & $\begin{array}{l}\text { Sp02 } \\
(\%)\end{array}$ & $\begin{array}{l}\operatorname{PASP}(\mathrm{mm} \text { Hg) } \\
(\text { mean } \pm \mathrm{SD}, \text { range })\end{array}$ & $\begin{array}{l}\text { NT-proBNP } \\
(\text { mean } \pm \text { SD, range) }\end{array}$ & $\begin{array}{l}\mathrm{BNP} \\
(\text { mean } \pm \mathrm{SD} \text {, range })\end{array}$ \\
\hline Kat $(1300 \mathrm{~m})$ (rest) & $96 \pm 0.5$ & $24.1 \pm 4.1(18-32)$ & $37 \pm 30(9.4-111)$ & $9.2 \pm 2(5-35)$ \\
\hline 3400 m (post-exercise) & & $36.8 \pm 8.2(23-56)$ & $111.2 \pm 96(35-379)$ & N/A \\
\hline $3400 \mathrm{~m}$ (rest) & $87.5 \pm 1.2$ & $31.6 \pm 8(21-53)$ & $334.8 \pm 541(27-2081)$ & $\mathrm{N} / \mathrm{A}$ \\
\hline $4270 \mathrm{~m}$ (post-exercise) & & $38.6 \pm 9.2(25-62)$ & $152 \pm 238(18-994)$ & $16.6 \pm 4(5-56)$ \\
\hline $4270 m$ (rest) & $85.1 \pm 1.2$ & $34.8 \pm 7.7(25-52)$ & $207 \pm 291(18-1045)$ & $28.9 \pm 9(5-101)$ \\
\hline $5150 \mathrm{~m}$ (post-exercise) & & $39.4 \pm 10.5(25-57)$ & $301 \pm 408(15-1539)$ & $32.3 \pm 8.8(5-95.6)$ \\
\hline $5150 \mathrm{~m}$ (rest) & $73.8 \pm 2$ & $35.7 \pm 8.4(25-53)$ & $259 \pm 346(18-1109)$ & $33.3 \pm 9.7(5-123)$ \\
\hline
\end{tabular}

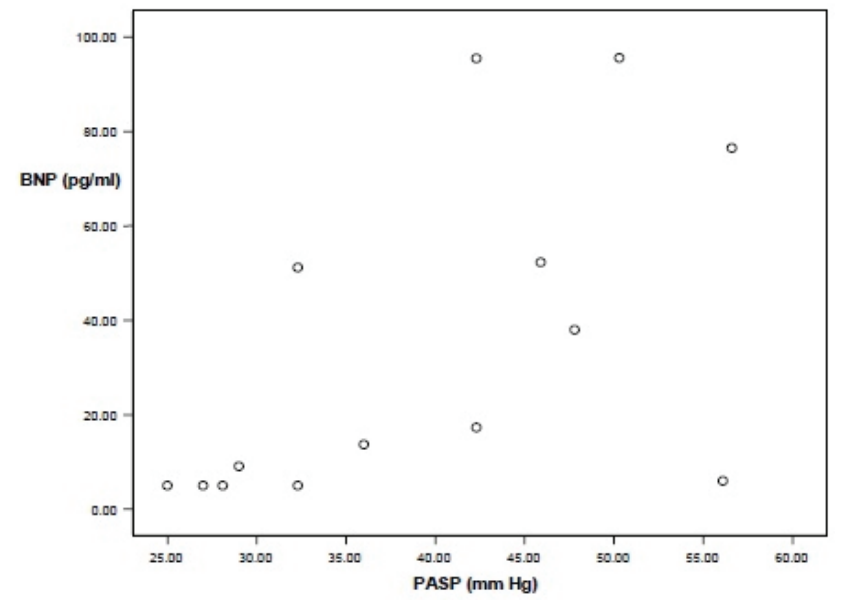

Fig. 1. At $5150 \mathrm{~m}$ post-exercise there was a significant correlation between BNP and PASP (rho=0.7, $\mathrm{p}=0.005)$.

PASP rose significantly $(\mathrm{p}=0.006)$ with altitude from $24 \pm 4$ at baseline to $39 \pm 11 \mathrm{~mm} \mathrm{Hg}$ at $5150 \mathrm{~m}$ (Table 1). Overall BNP significantly correlated with PASP $\quad(\mathrm{rho}=0.45, \quad \mathrm{p}<0.001)$ as did NT-proBNP (rho=0.508, $\mathrm{p}<0.001$ ). The correlation between BNP and PASP was strongest at $5150 \mathrm{~m}$ post-exercise $(\mathrm{rho}=0.7$, $\mathrm{p}=0.005)$ (Fig. 1).

At $5150 \mathrm{~m}$ post-exercise those with a $\mathrm{PASP} \geq 40$ $\mathrm{mm} \mathrm{Hg}(\mathrm{n}=8)$ (versus those with $\mathrm{PASP}<40 \mathrm{~mm} \mathrm{Hg})$ had higher post-exercise BNP (pg/ml): $54.5 \pm 36$ vs. $13.4 \pm 17$ $(\mathrm{p}=0.012)$. Their resting $\mathrm{BNP}$ at $5150 \mathrm{~m}$ was also higher: $57.3 \pm 43.4$ vs. $12.6 \pm 13$ ( $\mathrm{p}=0.017$ ) (Fig. 2). In the same participants there were non-significant differences in NTproBNP (pg/ml) at $5150 \mathrm{~m}: 500 \pm 516$ vs. $146 \pm 251$ (postexercise, $\mathrm{p}=0.083$ ) and $433 \pm 432$ vs. $117 \pm 162$ (resting, $\mathrm{p}=0.19$ ). BNP and NT-proBNP had been significantly higher in these participants at the previous altitude of $4270 \mathrm{~m}$ (BNP: $40 \pm 38.5$ vs. $16.3 \pm 27, \mathrm{p}=0.02$, NT-
proBNP: $308 \pm 356$ vs. $117 \pm 207, \mathrm{p}=0.028)$. In those with a pathological $(\geq 400 \mathrm{pg} / \mathrm{ml})$ rise in NT-proBNP at $5150 \mathrm{~m}$ $(n=4)$ PASP was significantly higher than those without: $45.9 \pm 7.5$ vs. $32.2 \pm 6.2 \mathrm{~mm} \mathrm{Hg}(\mathrm{p}=0.015)$ (Fig. 3$)$.

ROC analysis (to investigate the utility of BNP and NT-proBNP measured at HA in identifying a PASP $>40 \mathrm{~mm} \mathrm{Hg})$ revealed an AUC of $0.741(95 \% \mathrm{CI}$ $0.591-0.850, \mathrm{p}=0.001)$ and 0.743 (95\% CI 0.612-0.874, $\mathrm{p}<0.001$ ) for BNP and NT-proBNP respectively. An NTproBNP cut-off of $133 \mathrm{pg} / \mathrm{ml}$ gave a sensitivity of $70 \%$ and a specificity of $83 \%$ for identifying a high PASP.

Serum creatinine $\{\mu \mathrm{mol} / 1$, mean $\pm \mathrm{SD}$, (range) $\}$ at baseline was $78.11 \pm 8.8(63-95)$ and at $5150 \mathrm{~m} \mathrm{94.3} \pm 16.4$ $(76-142)(\mathrm{p}<0.001)$.

\section{Discussion}

The main, novel, finding of this study is that at HA those with a markedly elevated PASP appear to have higher BNP and NT-proBNP than those with a more moderate PASP.

An abnormally high PASP is a key feature in the pathophysiology of HAPE (Bartsch et al. 2005, Maggiorini et al. 2001) It has been suggested that the maximal PASP response to hypoxia (FiO2 12\%) in healthy participants is $40 \mathrm{~mm} \mathrm{Hg}$ (Grunig et al. 2000) Indeed, HAPE susceptible participants under hypoxic conditions have a much higher PASP than nonsusceptible participants ( $33 \pm 6$ vs. $50 \pm 9 \mathrm{~mm} \mathrm{Hg}$ ) (Berger et al. 2005) that can be further exacerbated by an exercise stimulus (Dehnert et al. 2005).

Although markedly elevated levels of BNP and NT-proBNP are used as a marker of CCF they are also moderately elevated in pulmonary hypertension at SL 


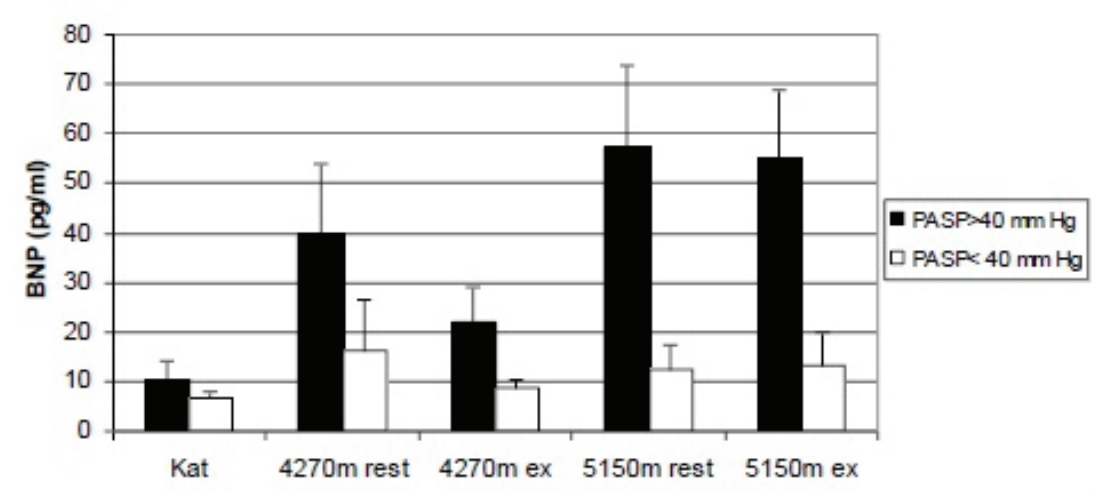

Fig. 2. BNP (mean $\pm S E M)$ with ascent according to a PASP $\geq 40 \mathrm{~mm} \mathrm{Hg}(\mathrm{n}=8)$ vs. $<40 \mathrm{~mm} \mathrm{Hg}$ at $5150 \mathrm{~m}$ post-exercise $(n=20$ at 1300 and $3400 \mathrm{~m}, \mathrm{n}=19$ at $4270 \mathrm{~m}$ and $\mathrm{n}=15$ at $5150 \mathrm{~m}$ ). Those with a PASP $\geq 40$ $\mathrm{mm} \mathrm{Hg}$ had post-exercise BNP $(\mathrm{pg} / \mathrm{ml})$ that was significantly $(p=0.012)$ higher $(54.5 \pm 36$ vs. $13.4 \pm 17$ ) as was resting BNP at $5150 \mathrm{~m}$ (BNP: $57.3 \pm 43.4$ vs. $12.6 \pm 13 p=0.017$ ).
(Blyth et al. 2007) There is a significant difference between their "normal" levels \{median BNP in a healthy population age $<45$ years is $7.7 \mathrm{pg} / \mathrm{ml}$, (Alere Triage BNP test product insert); median NT-proBNP in a healthy population age $<50$ years is $60.5 \mathrm{pg} / \mathrm{ml}$ (Bernstein et al. $2011)\}$ and those conventionally used to diagnose CCF ( $>100$ and $>400 \mathrm{pg} / \mathrm{ml}$ respectively). The levels we report associated with $\mathrm{PASP} \geq 40 \mathrm{~mm} \mathrm{Hg}$ are above the normal range, occasionally above the diagnostic level for $\mathrm{CCF}$, and consistent with those seen in other states of pulmonary hypertension.

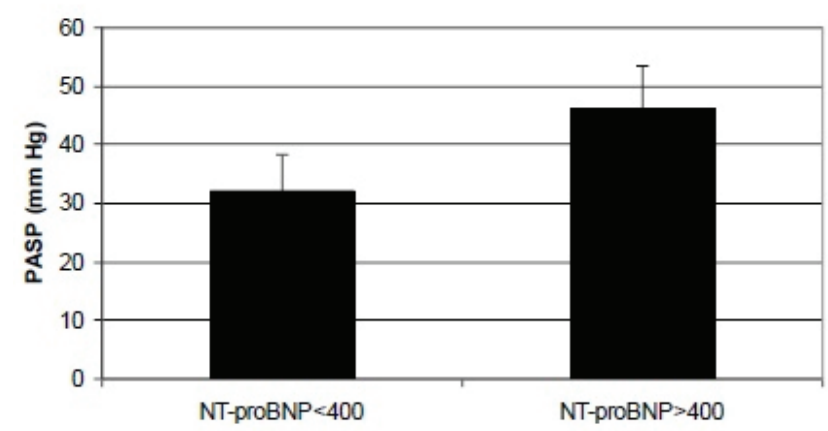

Fig. 3. In those with a pathological $(\geq 400 \mathrm{pg} / \mathrm{ml})$ rise in NTproBNP at $5150 \mathrm{~m}(\mathrm{n}=4)$ PASP $($ mean \pm SD) was significantly higher than those with a NT-proBNP $<400 \mathrm{pg} / \mathrm{ml} \quad(n=11)$ : $45.9 \pm 7.5$ vs. $32.2 \pm 6.2 \mathrm{~mm} \mathrm{Hg}(p=0.015)$.

Only one previous study has examined the relationship between NT-proBNP and PASP at HA (Toshner et al. 2008). This study reported no rise in NTproBNP on arrival at $5200 \mathrm{~m}$ following 5 days acclimatization at $3600 \mathrm{~m}$ despite a rise in PASP from $16.1 \mathrm{~mm} \mathrm{Hg}$ to $39.4 \mathrm{~mm} \mathrm{Hg}$. They reported an NTproBNP of $12.9 \mathrm{pg} / \mathrm{ml}$ on arrival compared to the $301 \mathrm{pg} / \mathrm{ml}$ we recorded at a very similar altitude using the same assay. A critical difference between these studies may be the exercise stimulus involved: our participants trekked to $5150 \mathrm{~m}$, as opposed to arriving at $5200 \mathrm{~m}$ by vehicle (Toshner et al. 2008). The fact that they reported very similar PASP to that which we observed suggests that exercise, which also increases PASP, may be a key factor in the rise in NT-proBNP at altitude. This is supported by our group's previous work that has shown no rise in BNP during acute hypobaric hypoxia with minimal exertion ( $<5 \mathrm{~min}$ ) (Boos et al. 2012, Woods et al. 2011b) despite inducing a rise in PASP from 24.3 to $35 \mathrm{~mm} \mathrm{Hg}$ (Boos et al. 2012).

Prolonged exertion at SL has been associated with a rise in natriuretic peptides (Leers et al. 2006, Neumayr et al. 2005, Scharhag et al. 2008) that has recently been suggested may relate to ventriculo-arterial mismatch (Sahlén et al. 2012). Conversely, short duration exercise is generally not associated with a rise in natriuretic peptides (Marumoto et al. 1995, Nishikimi et al. 1997). Increases in BNP and NT-proBNP under normoxic conditions have been noted to resolve within several to 24 hours (Leers et al. 2006, Neumayr et al. 2005, Scharhag et al. 2008) and may explain why no rise was previously documented in trekkers at HA when samples were only taken the following day at rest (Feddersen et al. 2009).

In our study the rise in BNP and NT-proBNP seen after exercise at HA not only persisted at rest the following day but had often risen higher despite a fall in PASP. Exercise is likely to exacerbate myocardial hypoxaemia at HA and be a greater stimulus to BNP release than hypoxia alone. In support of this there are hypoxia-responsive elements in the promoter sequence of the BNP gene (Luo et al. 2006) and hypoxia is known to stimulate natriuretic peptide release (Due-Andersen et al. 2008, Möllmann et al. 2010). In isolated human heart muscle (where the mechanical wall stress usually credited with stimulating BNP release has been removed) hypoxia induces a rapid increase in myocardial BNP expression (Möllmann et al. 2010). Further, acute myocardial hypoxaemia in pigs induces a marked rise in tissue BNP 
mRNA and a premature mRNA BNP followed by rapid release (Goetze et al. 2004). We therefore speculate that the initial rise in BNP and NT-proBNP following exercise at SL or HA may be due to release of proBNP from the small stored pool in cardiomyocytes. If there has been sufficient stimulus then in hypoxic conditions there may then be rapid up-regulation of BNP gene transcription that accounts for the persisting and elevated levels at rest.

It also makes physiological sense that the stressed and hypoxic myocardium should release BNP as it induces a natriuresis and is a vasodilator thereby acting to reduce myocardial wall stress. Infused BNP is known to attenuate hypoxaemia-induced increases in PASP and pulmonary vascular resistance (Cargill and Lipwoth 1995) and BNP levels are also employed to guide vasodilator therapy in pulmonary artery hypertension (Yap 2004).

We are not proposing that a high PASP is the sole determinant of a high BNP level at HA. BNP secretion may be stimulated by many factors. Although primarily stimulated by cardiomyocyte stretch and enddiastolic wall stress (Hall 2005) BNP is also stimulated by ischaemia, cardiac hypertrophy and oxidative stress (Nohria 2006). A high BNP may also occur in the context of cardiac transplant rejection where it does not reflect haemodynamic changes but is thought to reflect inflammatory changes within the myocardium (de Bold 2007). In the classical situation of CCF there is still significant heterogeneity in BNP levels. Patients with a similar degree of left ventricular systolic dysfunction demonstrate considerable inter-individual variation in BNP levels (Nohria and Givertz 2006) but this has not prevented BNP from becoming a useful marker of CCF. In a similar fashion we are not proposing that at HA PASP is an isolated stimulus to BNP but that there is some relationship between high PASP and a high BNP or NT-proBNP at HA that may ultimately prove useful in detecting not only high PASP but also cases of HAPE.

Limitations to our study include that although high PASP is a critical factor in the pathophysiology of HAPE our study does not include overt, clinical cases of HAPE. As such this report can only record an association between BNP and NT-proBNP and high PASP. Further work is needed to establish any relationship with subsequent HAPE. In addition, creatinine rose statistically significantly and theoretically a change in renal function could effect NT-proBNP levels (since NTproBNP is renally cleared). However, since the absolute rise was marginal and only 1 subject had a creatinine $>125 \mu \mathrm{mol} / \mathrm{l}(142 \mu \mathrm{mol} / \mathrm{l})$ we feel this is unlikely to have a significant effect on the overall levels of NT-proBNP and the findings of this study.

The correlation between PASP and BNP and NT-proBNP were moderate but highly significant and the ROC analysis suggests that both natriuretic peptides should be further evaluated for their utility in identifying a high PASP at HA in a larger cohort. While an NTproBNP cut-off of $133 \mathrm{pg} / \mathrm{ml}$ that gives a sensitivity of $70 \%$ and a specificity of $83 \%$ for identifying a high PASP may not be perfect, in the context of the cohort studied it is encouraging.

In conclusion, HAPE is a serious condition with an incidence estimated at up to $4 \%$ at $4559 \mathrm{~m}$ (Maggiorini et al. 2001). The increasing number of visitors to HA represent a significant challenge in the early recognition, treatment, and possible evacuation of those who succumb to HAPE. Pulmonary hypertension, a key feature, is difficult to diagnose without either invasive or non-invasive techniques that require expertise and equipment beyond the realm of most conventional HA expeditions. Any association between high PASP and BNP or NT-proBNP at HA could therefore prove clinically useful in differentiating HAPE from other medical conditions, particularly in the early stages. Our data suggest that BNP and/or NT-proBNP may have potential as a marker of pulmonary hypertension in previously healthy participants at HA and as such, particularly with near-patient testing, may facilitate identification of a pathophysiological state that without appropriate management may be life-threatening.

\section{Conflict of Interest}

There is no conflict of interest.

\section{Acknowledgements}

All participants of Exercise Khumbu Ramble. Med and GS, DE and S, Foxhill, Donnington for equipment support. Alere Ltd, Cheshire for unconditional loan of Biosite machines. There is no conflict of interest to declare. This research was sponsored by the Surgeon General's Research Strategy Group and funded by the Joint Medical Command and the Drummond Foundation. 


\section{References}

BARTSCH P, MAIRBAURL H, MAGGIORINI M, SWENSON ER: Physiological aspects of high-altitude pulmonary edema. J Appl Physiol 98: 1101-1110, 2005.

BERGER M, HESSE C, DEHNERT C, SIEDLER H, KLEINBONGARD P, BARDENHEUER HJ, KELM M, BÄRTSCH P, HAEFELI WE: Hypoxia impairs systemic endothelial function in individuals prone to highaltitude pulmonary edema. Am J Respir Crit Care Med 172: 763-767, 2005.

BERNSTEIN LH, ZIONS MY, ALAM ME, HAQ SA, HEITNER JF, ZARICH S, SEAMONDS B, BERGER S: What is the best approximation of reference normal forNT-proBNP? Clinical levels for enhanced assessment of NTproBNP (CLEAN). J Med Lab Diag 2: 16-21, 2011.

BLYTH KG, GROENNING BA, MARK PB, MARTIN TN, FOSTER JE, STEEDMAN T, MORTON JJ, DARGIE HJ, PEACOCK AJ: NT-proBNP can be used to detect right ventricular systolic dysfunction in pulmonary hypertension. Eur Respir J 29: 737-744, 2007.

BOOS CJ, HODKINSON P, MELLOR A, GREEN NP, WOODS DR: The effects of acute hypobaric hypoxia on arterial stiffness and endothelial function and its relationship to changes in pulmonary artery pressure and left ventricular diastolic function. High Alt Med Biol 13: 105-111, 2012.

CARGILL RI, LIPWORTH BJ: Acute effects of ANP and BNP on hypoxic pulmonary vasoconstriction in humans. Brit J Clin Pharmacol 40: 585-590, 1995.

CASALS G, ROS J, SIONIS A, DAVIDSON MM, MORALES-RUIZ M, JIMÉNEZ W: Hypoxia induces B-type natriuretic peptide release in cell lines derived from human cardiomyocytes. Am J Physiol 297: H550-H555, 2009.

DE BOLD AJ: Determinants of brain natriuretic peptide gene expression and secretion in acute cardiac allograft rejection. Curr Opin Cardiol 22: 146-150, 2007.

DEHNERT C, GRÜNIG E, MERELES D, VON LENNEP N, BÄRTSCH P: Identification of individuals susceptible to high-altitude pulmonary oedema at low altitude. Eur Respir $J$ 25: 545-551, 2005.

DUE-ANDERSEN R, PEDERSEN-BJERGAARD U, HØI-HANSEN T, OLSEN NV, KISTORP C, FABER J, BOOMSMA F, THORSTEINSSON B: NT-pro-BNP during hypoglycemia and hypoxemia in normal subjects: impact of renin-angiotensin system activity. J Appl Physiol 104: 1080-1085, 2008.

FEDDERSEN B, AUSSERER H, HADITSCH B, FRISCH H, NOACHTAR S, STRAUBE A: Brain natriuretic peptide at altitude: relationship to diuresis, natriuresis, and mountain sickness. Aviat Space Environ Med 80: 108-111, 2009.

GOETZE JP, GORE A, MOLLER CH, STEINBRUCHEL DA, REHFELD JF, NIELSEN LB: Acute myocardial hypoxia increases BNP gene expression. FASEB J 18: 1928-1930, 2004.

GRUNIG E, MERELES D, HILDEBRANDT W, SWENSON ER, KUBLER W, KUECHERER H, BARTSCH P: Stress Doppler echocardiography for identification of susceptibility to high altitude pulmonary edema. $J \mathrm{Am}$ Coll Cardiol 35: 980-987, 2000.

HALL C: NT-ProBNP: the mechanism behind the marker. J Card Fail 11 (5 Suppl): S81-S83, 2005.

HALL DP, DUNCAN K, BAILLIE JK: High altitude pulmonary oedema. J R Army Med Corps 157: 68-72, 2011.

KERR AJ, RAFFEL OC, WHALLEY GA, ZENG I, STEWART RA: Elevated B-type natriuretic peptide despite normal left ventricular function on rest and exercise stress echocardiography in mitral regurgitation. Eur Heart J 29: 363-370, 2008.

LEERS MP, SCHEPERS R, BAUMGARTEN R: Effects of a long-distance run on cardiac markers in healthy athletes. Clin Chem Lab Med 44: 999-1003, 2006.

LUO Y, JIANG C, BELANGOR AJ, AKITA GY, WADSWORTH SC, GREGORY RJ, VINCENT KA: A constitutively active hypoxia-inducible factor-1 $\alpha / \mathrm{VP} 16$ hybrid factor activates expression of the human Btype natriuretic peptide gene. Mol Pharmacol 69: 1953-1962, 2006.

MAGGIORINI M, MÉLOT C, PIERRE S, PFEIFFER F, GREVE I, SARTORI C, LEPORI M, HAUSER M, SCHERRER U, NAEIJE R: High-altitude pulmonary edema is initially caused by an increase in capillary pressure. Circulation 103: 2078-2083, 2001. 
MARUMOTO K, HAMADA M, HIWADA K: Increased secretion of atrial and brain natriuretic peptides during acute myocardial ischaemia induced by dynamic exercise in patients with angina pectoris. Clin Sci Colch 88: 551$556,1995$.

MÖLLMANN H, NEF HM, KOSTIN S, DRAGU A, MAACK C, WEBER M, TROIDI C, ROLF A, ELSÄSSER A, BÖHM M, BRANTNER R, HAMM CW, HOLUBARSCH CJ: Ischemia triggers BNP expression in the human myocardium independent from mechanical stress. Int J Cardiol 143: 289-297, 2010.

NEUMAYR G, PFISTER R, MITTERBAUER G, EIBL G, HOERTNAGL H: Effect of competitive marathon cycling on plasma $\mathrm{N}$-terminal pro-brain natriuretic peptide and cardiac troponin $\mathrm{T}$ in healthy recreational cyclists. $\mathrm{Am} \mathrm{J}$ Cardiol 96: 732-735, 2005.

NISHIKIMI T, MORIMOTO A, ISHIKAWA K, SAITO Y, KANGAWA K, MATSUO H, KITAMURA K, TAKISHITA S, MATSUOKA H: Different secretion patterns of adrenomedullin, brain natriuretic peptide, and atrial natriuretic peptide during exercise in hypertensive and normotensive subjects. Clin Exp Hypertens 19: 503-518, 1997.

NOHRIA A, GIVERTZ MM: B-type natriuretic peptide and the stressed heart. J Am Coll Cardiol 47: 749-751, 2006.

SAHLÉN A, SHAHGALDI K, AAGAARD P, MANOURAS A, WINTER R, BRAUNSCHWEIG F: Altered ventriculo-arterial coupling during exercise in athletes releasing biomarkers after endurance running. Eur $J$ Appl Physiol 112: 4069-4079, 2012.

SCHARHAG J, MEYER T, AURACHER M, MÜLLER M, HERRMANN M, GABRIEL H, HERRMANN W, KINDERMANN W: Exercise-induced increases in NT-proBNP are not related to the exercise-induced immune response. Br J Sports Med 42: 383-385, 2008.

TOSHNER MR, THOMPSON AAR, IRVING JB, BAILLIE JK, MORTON JJ, PEACOCK AJ: NT-proBNP does not rise on acute ascent to high altitude. High Alt Med Biol 9: 1-4, 2008.

WOODS D, HOOPER T, HODKINSON P, BALL S, WAKEFORD R, PEASTON B, BAIRSTO C, GREEN N, MELLOR A: Effects of altitude exposure on brain natriuretic peptide in humans. Eur J Appl Physiol 111: 2687-2693, 2011a.

WOODS D, HOOPER T, MELLOR A, HODKINSON P, WAKEFORD R, PEASTON B, BALL S, GREEN N: Brain natriuretic peptide and acute hypobaric hypoxia in humans. J Physiol Sci 61: 217-220, $2011 \mathrm{~b}$.

WOODS DR, BEGLEY J, STACEY M, SMITH C, BOOS CJ, HOOPER T, HAWKINS A, HODKINSON P, GREEN N, MELLOR A: Severe acute mountain sickness, brain natriuretic peptide and NT-proBNP in humans. Acta Physiol (Oxf) 205: 349-355, 2012.

YAP LB: B-type natriuretic peptide and the right heart. Heart Fail Rev 9: 99-105, 2004.

YOCK PG, POPP R: Noninvasive estimation of right ventricular systolic pressure by Doppler ultrasound in patients with tricuspid regurgitation. Circulation 70: 657-662, 1984. 